\title{
Synthesis and anticancer effects of conjugates of doxorubicin and unsaturated fatty acids (LNA and DHA)
}

\author{
Magdalena Mielczarek-Puta' ${ }^{1}$ Marta Struga ${ }^{1} \cdot$ Piotr Roszkowski ${ }^{2}$
}

Received: 15 July 2019 / Accepted: 7 September 2019 / Published online: 25 September 2019

(c) The Author(s) 2019

\begin{abstract}
Doxorubicin (DOX) is a leading cytostatic drug with many adverse effects in use. We are still looking for methods that will allow us to preserve the therapeutic effect against the tumor cells and reduce the toxicity to the normal cells. In our work, we obtained amide derivatives of DOX by reaction of the amino group with $\alpha$-linolenic (LNA) and docosahexaenoic (DHA) acids $(\mathbf{2}, \mathbf{3})$, as well as double-substituted derivatives via amide and ester linkages $(\mathbf{4}, \mathbf{5})$. The structures of the compounds were confirmed by Proton Nuclear Magnetic Resonance (1H NMR), Carbon-13 Nuclear Magnetic Resonance (13C NMR), and High Resolution Mass Spectrometry (HRMS) analyses. For all compounds 3-(4,5-dimethylthiazolyl-2)-2,5diphenyltetrazolium bromide (MTT) assay was used to determine the cytotoxic effect on human cancer cell lines (SW480, SW620, and PC3) and Chinese hamster lung fibroblasts (V79) that were used as a control. The cytotoxic activity was established by calculation of the inhibitory concentration $\mathrm{IC}_{50}$. In addition, a cytotoxic capacity against tumor cells for tested compounds was expressed as a selectivity factor (selectivity index, SI). Lactate dehydrogenase (LDH) assay was performed for all compounds to assess the level of cell damage. To explain the basic mechanism of cell death induction the Annexin V-FITC/IP flow cytometry analysis was investigated. We found that all studied conjugates exhibit lower cytotoxicity but higher selectivity than DOX. Among the all derivatives, the conjugates formed by the amide and ester linkages $(\mathbf{4}, \mathbf{5})$ were found to be more promising compared with conjugates $(\mathbf{2}, \mathbf{3})$ formed only by the amide linkage. They show high cytotoxicity toward the tumor cell lines and moderate cytotoxicity towards the normal cell line.
\end{abstract}

Keywords Doxorubicin derivatives $\cdot$ Unsaturated fatty acids $\cdot$ Cytotoxicity $\cdot$ Apoptosis

\section{Introduction}

Application of chemotherapy seems to be crucial in the fight against cancer diseases. Nowadays many different active substances are used to inhibit the proliferation of cancer cells, but still there is a need to find substances, which act specifically as anticancer factors. Availability of new technologies related to research on tumor pathogenesis

Supplementary information The online version of this article (https:// doi.org/10.1007/s00044-019-02443-0) contains supplementary material, which is available to authorized users.

Marta Struga

marta.struga@wum.edu.pl

1 Chair and Department of Biochemistry, Medical University of Warsaw, Banacha 1, 02-097 Warszawa, Poland

2 Faculty of Chemistry, University of Warsaw, Pasteura 1, 02-093 Warsaw, Poland designated new strategies of searching active compounds, which can be used as medications. These compounds can act independently or in combination with other medicines (combined therapy) and can be used in treatment of cancer diseases (Xu and Mao 2016; Narang and Desai 2009).

Doxorubicin (DOX) is a multidirectional chemotherapy agent (Gewirtz 1999), which mechanism of action includes intercalation and alkylation of DNA (Young et al. 1981), inhibition of RNA and DNA polymerases (Zunina et al. 1975), or topoisomerase II (Binaschi et al. 2001). The anticancer action of DOX is also mediated by chelating of iron, zinc and copper ions, formation of reactive oxygen species (ROS) (Minotti et al. 2004; Marnett et al. 2003) and binding to lipids in cell membrane resulting in the changes of its permeability (Pessah et al. 1990; Oakes et al. 1990; Bielack et al. 1996).

The use of DOX is associated with very high risks, such as cardiomyopathy and congestive heart failure (Lenaz and Page 1976; Weiss 1992; Johnson et al. 1986; Lampidis et al. 1981). The improvement in the effectiveness of anticancer 
properties of DOX though conjugation or derivatization could be an alternative option to reduce time and costs required to develop a new anticancer agent (Hidayat et al. 2018). To design a tumor-targeting drug, it is crucial to understand the tumor cell microenvironment. It is well known that cancer cells differ from normal cells. They display uncontrolled growth and usually require a large amount of various nutrients (Jaracz et al. 2005). One of the most important compounds that affect cell metabolism are polyunsaturated fatty acids (PUFAs). In addition, compared with normal cells, PUFAs are more avidly taken up by tumor cells (Sauer et al. 2000; Koralek et al. 2006; Coakley et al. 2009). The most important $\omega$-3 PUFAs are: $\alpha$-linolenic (cis9,12,15-octadecatrienoic, LNA) and cis-7,7,10,13,16,19docosahexaenoic (DHA). $\omega$-3 fatty acids (e.g., DHA) can bind to cognate receptors on cancer cells and then exert a targeting effect (Sauer et al. 2000). They can play an important role in delay of the cancer progression by modulating hormone receptors, Akt kinase, and nuclear factors $\kappa_{B}$ as well as being the target for ROS (Das 2004; Narayanan et al. 2005). It is known that they inhibit the formation of the tumor growth promotor 13-hydroxy-octadecadienoic acid (13-HODE) and they have a cardioprotective effect, which can reduce the cardiotoxicity of DOX (Sauer et al. 2001; De Roos et al. 2009).

Conjugation of drug with fatty acids increases its lipid solubility what facilitates permeation into the cell membrane. These conjugates have a longer plasma half-life and a higher bioavailability (Engelbrecht 2011). Thus, fatty acids (especially PUFAs) have been used as tumor-specific ligands to deliver antitumor drugs selectively (Kuznetsova et al. 2006; Tanmahasamut et al. 2004).

To increase the therapeutic index of DOX and to attenuate its toxicity toward normal tissues, conjugates with either $\alpha$-linolenic acid (LNA) or palmitic acid by a hydrazone or an amide bond were synthesized. DOX-LNA hydrazine decreased the tumor growth and improved the survival time of tumor-bearing nude mice (Liang 2014).

Wang et al. had already reported a conjugate with DHA by a hydrazone linker that showed antitumor efficacy in mice bearing B16 melanoma (Wang et al. 2006).

On the basis of recent studies on the biological and pharmacological DOX, LNA, and DHA properties our research focus on synthesis a novel conjugated compounds to obtain more effective antitumor agents.

\section{Materials and methods}

\section{General}

Dichloromethane, dimethylformamide, and methanol were supplied from Sigma-Aldrich. All chemicals were of analytical grade and were used without any further purification. The Nuclear Magnetic Resonance (NMR) spectra were recorded on a Bruker AVANCE spectrometer operating at $300 \mathrm{MHz}$ for ${ }^{1} \mathrm{H}$ NMR and at $75 \mathrm{MHz}$ for ${ }^{13} \mathrm{C}$ NMR. The spectra were measured in $\mathrm{CDCl}_{3}$ and are given as $\delta$ values (in $\mathrm{ppm}$ ) relative to TMS. The spectra were measured in $\mathrm{CDCl}_{3}$ and are given as $\delta$ values (in ppm) relative to TMS. Mass spectral ESI measurements were carried out on Waters ZQ Micromass instruments with quadruple mass analyzer. TLC analyses were performed on silica gel plates (Merck Kiesegel $\mathrm{GF}_{254}$ ) and visualized using UV light or iodine vapour. Column chromatography was carried out at atmospheric pressure using silica gel 60 (230-400 mesh, Merck) and using dichloromethane/ methanol $(0-2 \%)$ mixture as eluent.

\section{General procedure for amide synthesis $\mathbf{2}$ and $\mathbf{3}$}

A solution of carboxylic acid (1 eqv, $0.34 \mathrm{mmol})$ and $\mathrm{N}, \mathrm{N}^{\prime}$-dicyclohexylcarbodiimide (DCC) $(1.5 \mathrm{eqv}, 106.8 \mathrm{mg}$, $0.52 \mathrm{mmol})$ in dry $\mathrm{CH}_{2} \mathrm{Cl}_{2} / \mathrm{DMF}(9: 1,28 \mathrm{~mL})$ was stirred for $15 \mathrm{~min}$ at $22^{\circ} \mathrm{C}$. Then, DMAP ( $\left.1.1 \mathrm{eqv}, 46.4 \mathrm{mg}, 0.38 \mathrm{mmol}\right)$ and $\mathrm{DOX} \cdot \mathrm{HCl}(1 \mathrm{eqv}, 200 \mathrm{mg}, 0.34 \mathrm{mmol})$ were added and the red suspension was stirred for $20 \mathrm{~h}$ at $22-23^{\circ} \mathrm{C}$ in the dark. Then reaction mixture was filtered, solid was washed with $\mathrm{CH}_{2} \mathrm{Cl}_{2}(2 \times 20 \mathrm{~mL})$, and next the combined organic phases was washed with $1.5 \% \mathrm{HCl}$ water solution $(2 \times$ $15 \mathrm{~mL}$ ). The organic layer was dried over $\mathrm{MgSO}_{4}$ and after evaporation of the solvent under reduced pressure the product was isolated using column chromatography on silica gel and $\mathrm{CH}_{2} \mathrm{Cl}_{2}: \mathrm{MeOH}$ mixture $(0-2 \% \mathrm{MeOH})$ as an eluent.

\section{General procedure for amide/ester synthesis 4 and 5}

A solution of carboxylic acid (2 eqv, $0.34 \mathrm{mmol})$ and $\mathrm{N}, \mathrm{N}^{\prime}$-dicyclohexylcarbodiimide (DCC) $(2.5 \mathrm{eqv}, 89.0 \mathrm{mg}$, $0.43 \mathrm{mmol})$ in dry $\mathrm{CH}_{2} \mathrm{Cl}_{2} / \mathrm{DMF}(9: 1,14 \mathrm{~mL})$ was stirred for $15 \mathrm{~min}$ at $22^{\circ} \mathrm{C}$. Then, DMAP $(1.1 \mathrm{eqv}, 23.2 \mathrm{mg}$, $0.19 \mathrm{mmol}$ ) and DOX $\mathrm{HCl}(1 \mathrm{eqv}, 100 \mathrm{mg}, 0.17 \mathrm{mmol}$ ) were added and the red suspension was stirred for $20 \mathrm{~h}$ at $22-23{ }^{\circ} \mathrm{C}$ in the dark. Then reaction mixture was filtered, solid was washed with $\mathrm{CH}_{2} \mathrm{Cl}_{2}(2 \times 10 \mathrm{~mL})$, and next the combined organic phases were washed with $1.5 \% \mathrm{HCl}$ water solution $(2 \times 10 \mathrm{~mL})$. The organic layer was dried over $\mathrm{MgSO}_{4}$ and after evaporation of the solvent under reduced pressure the product was isolated using column chromatography on silica gel and $\mathrm{CH}_{2} \mathrm{Cl}_{2}: \mathrm{MeOH}$ mixture $(0-1 \% \mathrm{MeOH})$ as an eluent.

\section{Doxorubicin linolenic acid amide (2)}

Red solidifying oil, $190 \mathrm{mg}(68 \%) .[\alpha]_{\mathrm{D}}^{23}=+210.0(c 0.5$, $\mathrm{CH}_{2} \mathrm{Cl}_{2}$ ). 
${ }^{1} \mathrm{H} \mathrm{NMR}\left(\mathrm{CDCl}_{3}, 300 \mathrm{MHz}\right) \delta(\mathrm{ppm}): 0.96(\mathrm{t}, J=7.5 \mathrm{~Hz}$, $\left.1^{\prime \prime}-3 \mathrm{H}\right), 1.25-1.28$ (m, 12", 13", 14", 15"-8H), 1.29 (d, $J=$ $6.6 \mathrm{~Hz}, 6^{\prime}-3 \mathrm{H}$ ), 1.54 (quint, $J=6.9 \mathrm{~Hz}, 16^{\prime \prime}-2 \mathrm{H}$ ), 1.70-1.84 (m, 2'-2H), 2.00-2.16 (m, 2", 11", 17"-6H), 2.30 (d, J= $14.7 \mathrm{~Hz}, 8 \mathrm{ax}-1 \mathrm{H}), 2.47$ (d, $J=5.1 \mathrm{~Hz}, 8 \mathrm{eq}-1 \mathrm{H}), 2.69-2.79$ (m, 5", 8"-4H), 2.83 (d, $J=18.6 \mathrm{~Hz}, 10 \mathrm{ax}-1 \mathrm{H}), 3.11(\mathrm{t}, J=$ $4.8 \mathrm{~Hz}, 14-\mathrm{OH}-1 \mathrm{H}), 3.17$ (d, $J=17.1 \mathrm{~Hz}, 10 \mathrm{eq}-1 \mathrm{H}), 3.63$ $\left(\mathrm{dd}, J=8.1 \mathrm{~Hz}, J=2.7 \mathrm{~Hz}, \mathrm{~Hz}, 4^{\prime}-1 \mathrm{H}\right), 4.03$ (s, $\left.\mathrm{OCH}_{3}-3 \mathrm{H}\right)$, 4.10-4.18 (m, 3'-1H, 5'-1H), 4.52 (s, 9-OH-1H), 4.74 (d, $J=5.1 \mathrm{~Hz}, 14-2 \mathrm{H}), 5.16-5.19$ (m, 7-1H), 5.17-5.40 (m, 3", 4", 6", 7", 9", 10"-6H), 5.46 (d, J=3.9 Hz, 1'-1H), 5.95 (d, $\left.J=8.4 \mathrm{~Hz}, 4^{\prime}-\mathrm{OH}-1 \mathrm{H}\right), 7.35(\mathrm{dd}, J=8.7 \mathrm{~Hz}, J=1.2 \mathrm{~Hz}, 3-$ $1 \mathrm{H}), 7.76(\mathrm{dd}, J=7.5 \mathrm{~Hz}, J=0.9 \mathrm{~Hz}, 1-1 \mathrm{H}), 7.96(\mathrm{dd}, J=$ $7.8 \mathrm{~Hz}, J=1.2 \mathrm{~Hz}, 2-1 \mathrm{H}$ ), 13.10 (s, 6-OH-1H), 13.90 (s-11$\mathrm{OH}-1 \mathrm{H}) .{ }^{13} \mathrm{C} \mathrm{NMR}\left(\mathrm{CDCl}_{3}, 75 \mathrm{MHz}\right) \delta(\mathrm{ppm}): 14.2\left(\mathrm{C}-1^{\prime \prime}\right)$, $16.8\left(\mathrm{C}^{\prime} 6^{\prime}\right), 20.5\left(\mathrm{C}-2^{\prime \prime}\right), 25.5\left(\mathrm{C}-5^{\prime \prime}\right), 25.5\left(\mathrm{C}-8^{\prime \prime}\right), 25.6(\mathrm{C}-$ 16"), 27.1 (C-11"), 29.1 (C-15"), 29.2 (C-14"), 29.2 (C13"), $29.5\left(\mathrm{C}-12^{\prime \prime}\right), 33.8$ (C-17"), 35.6 (C-10), 36.7 (C-8), 45.0 $\left(\mathrm{C}-3^{\prime}\right), 56.6\left(\mathrm{C}-\mathrm{OCH}_{3}\right), 65.5(\mathrm{C}-14), 67.2\left(\mathrm{C}-5^{\prime}\right), 69.5(\mathrm{C}-$ 4'), 69.7 (C-7), 76.4 (C-9), 100.8 (C-1'), 111.2 (C-5a), 111.4 (C-11a), 118.4 (C-3), 119.7 (C-1), 120.6 (C-4a), $127.0\left(\mathrm{C}-4^{\prime \prime}\right), 127.6\left(\mathrm{C}-6^{\prime \prime}\right), 128.2\left(\mathrm{C}-7^{\prime \prime}\right), 128.2\left(\mathrm{C}-9^{\prime \prime}\right)$, $130.2\left(\mathrm{C}-10^{\prime \prime}\right), 131.9\left(\mathrm{C}-3^{\prime \prime}\right), 133.5$ (C-10a), 133.5 (C-12a), 135.2 (C-6a), 135.7 (C-2), 155.4 (C-11), 156.1 (C-6), 160.8 (C-4), 172.5 (C-18"), 186.3 (C-12), 186.8 (C-5), 213.9 (C13).

High Resolution Mass Spectrometry (HRMS) (ESI) m/z 826.3742 (calcd for $\mathrm{C}_{45} \mathrm{H}_{57} \mathrm{NO}_{12} \mathrm{Na}[\mathrm{M}+\mathrm{Na}]^{+}, 826.3778$ ).

\section{Doxorubicin DHA acid amide (3)}

Red solidifying oil, $126 \mathrm{mg}(43 \%) \cdot[\alpha]_{\mathrm{D}}^{23}=+185.0(c 0.5$, $\mathrm{CH}_{2} \mathrm{Cl}_{2}$ ).

${ }^{1} \mathrm{H} \mathrm{NMR}\left(\mathrm{CDCl}_{3}, 300 \mathrm{MHz}\right) \delta(\mathrm{ppm}): 0.96(\mathrm{t}, J=7.5 \mathrm{~Hz}$, $\left.1^{\prime \prime}-3 \mathrm{H}\right), 1.29\left(\mathrm{~d}, J=6.6 \mathrm{~Hz}, 6^{\prime}-3 \mathrm{H}\right), 1.70-1.87\left(\mathrm{~m}, 2^{\prime}-2 \mathrm{H}\right)$, 2.01-2.08 (m, 21" -2H), 2.12-2.20 (m, 8-2H), 2.28-2.38 (m, $\left.2^{\prime \prime}, 20^{\prime \prime}-4 \mathrm{H}\right), 2.77-2.83$ (m, 5", 8", 11" $\left.14^{\prime \prime}, 17^{\prime \prime}-10 \mathrm{H}\right), 2.87$ $(\mathrm{d}, J=19.2 \mathrm{~Hz}, 10 \mathrm{ax}-1 \mathrm{H}), 3.08(\mathrm{t}, J=5.1 \mathrm{~Hz}, 14-\mathrm{OH}-1 \mathrm{H})$, $3.19(\mathrm{dd}, J=19.2 \mathrm{~Hz}, J=1.8 \mathrm{~Hz}, 10 \mathrm{eq}-1 \mathrm{H}), 3.63$ (d, $J=$ $\left.6.6 \mathrm{~Hz}, 4^{\prime}-1 \mathrm{H}\right), 4.05\left(\mathrm{~s}, \mathrm{OCH}_{3}-3 \mathrm{H}\right), 4.09-4.18\left(\mathrm{~m}, 3^{\prime}-1 \mathrm{H}\right.$, $\left.5^{\prime}-1 \mathrm{H}\right), 4.51(\mathrm{~s}, 9-\mathrm{OH}-1 \mathrm{H}), 4.75$ (d, $\left.J=5.1 \mathrm{~Hz}, 14-2 \mathrm{H}\right)$, 5.20-5.23 (m, 7-1H), 5.25-5.43 (m, 3", 4", 6", 7", 9", 10", $\left.12^{\prime \prime}, 13^{\prime \prime}, 15^{\prime \prime}, 16^{\prime \prime}, 18^{\prime \prime}, 19^{\prime \prime}-12 \mathrm{H}\right), 5.47$ (d, J=3.9 Hz, 1'$1 \mathrm{H}), 5.90\left(\mathrm{~d}, J=8.4 \mathrm{~Hz}, 4^{\prime}-\mathrm{OH}-1 \mathrm{H}\right), 7.36(\mathrm{dd}, J=8.7 \mathrm{~Hz}$, $J=1.2 \mathrm{~Hz}, 3-1 \mathrm{H}), 7.76(\mathrm{dd}, J=7.5 \mathrm{~Hz}, J=0.9 \mathrm{~Hz}, 1-1 \mathrm{H})$, $7.98(\mathrm{dd}, J=7.5 \mathrm{~Hz}, J=1.2 \mathrm{~Hz}, 2-1 \mathrm{H}), 13.13$ (s, 6-OH1H), 13.92 (s-11-OH-1H). ${ }^{13} \mathrm{C} \mathrm{NMR}\left(\mathrm{CDCl}_{3}, 75 \mathrm{MHz}\right) \delta$ (ppm): $14.2\left(\mathrm{C}-1^{\prime \prime}\right), 16.8\left(\mathrm{C}-6^{\prime}\right), 20.5\left(\mathrm{C}-2^{\prime \prime}\right), 23.3\left(\mathrm{C}-20^{\prime \prime}\right)$, $25.5\left(\mathrm{C}-5^{\prime \prime}\right), 25.5\left(\mathrm{C}-17^{\prime \prime}\right), 25.6\left(\mathrm{C}-8^{\prime \prime}, 11^{\prime \prime}, 14^{\prime \prime}\right), 29.9\left(\mathrm{C}-2^{\prime}\right)$, $33.8\left(\mathrm{C}-21^{\prime \prime}\right), 35.6(\mathrm{C}-10), 36.3(\mathrm{C}-8), 45.1\left(\mathrm{C}-3^{\prime}\right), 56.6(\mathrm{C}-$ $\left.\mathrm{OCH}_{3}\right), 65.5(\mathrm{C}-14), 67.2\left(\mathrm{C}-5^{\prime}\right), 69.4\left(\mathrm{C}-4^{\prime}\right), 69.7(\mathrm{C}-7)$, 76.5 (C-9), $100.7\left(\mathrm{C}-1^{\prime}\right), 111.2$ (C-5a), 111.4 (C-11a), 118.4 (C-3), 119.8 (C-1), 120.6 (C-4a), 127.0 (C-4"), 127.8 (C- $\left.6^{\prime \prime}\right), 128.0\left(\mathrm{C}-7^{\prime \prime}\right), 128.0\left(\mathrm{C}-9^{\prime \prime}\right), 128.0\left(\mathrm{C}-10^{\prime \prime}\right), 128.0(\mathrm{C}-$ $\left.12^{\prime \prime}\right), 128.2\left(\mathrm{C}-13^{\prime \prime}\right), 128.2\left(\mathrm{C}-15^{\prime \prime}\right), 128.2\left(\mathrm{C}-16^{\prime \prime}\right), 128.5$ $\left(\mathrm{C}-18^{\prime \prime}\right), 129.3\left(\mathrm{C}-19^{\prime \prime}\right), 132.0\left(\mathrm{C}-3^{\prime \prime}\right), 133.5$ (C-10a), 133.5 (C-12a), 135.3 (C-6a), 135.7 (C-2), 155.5 (C-11), 156.1 (C6), 160.9 (C-4), 171.7 (C-22"), 186.4 (C-12), 186.8 (C-5), 213.9 (C-13).

HRMS (ESI) m/z 876.3892 (calcd for $\mathrm{C}_{49} \mathrm{H}_{59} \mathrm{NO}_{12} \mathrm{Na}$ $\left.[\mathrm{M}+\mathrm{Na}]^{+}, 876.3935\right)$.

\section{Doxorubicin linolenic acid amide/ester (4)}

Red solidifying oil, $90 \mathrm{mg}(49 \%) .[\alpha]_{\mathrm{D}}^{23}=+156.4(c \quad 0.5$, $\mathrm{CH}_{2} \mathrm{Cl}_{2}$ ).

${ }^{1} \mathrm{H} \mathrm{NMR}\left(\mathrm{CDCl}_{3}, 300 \mathrm{MHz}\right) \delta(\mathrm{ppm}): 0.96(\mathrm{t}, J=7.5 \mathrm{~Hz}$, $\left.1^{\prime \prime}-3 \mathrm{H}\right), 0.98\left(\mathrm{t}, J=7.5 \mathrm{~Hz}, 1^{*}-3 \mathrm{H}\right), 1.26-1.35$ (m, 12", 13", $\left.14^{\prime \prime}, 15^{\prime \prime}, 12^{*}, 13^{*}, 14^{*}, 15^{*}-16 \mathrm{H}\right), 1.32\left(\mathrm{~d}, J=6.6 \mathrm{~Hz}, 6^{\prime}-\right.$ $3 \mathrm{H}$ ), 1.55 (quint, $\left.J=6.9 \mathrm{~Hz}, 16^{\prime \prime}-2 \mathrm{H}\right), 1.66-1.83\left(\mathrm{~m}, 2^{\prime}\right.$, $\left.16^{*}-4 \mathrm{H}\right), 1.90-2.13$ (m, 2", 11", 17", 2*, 11*, 17*-12H), 2.32-2.39 (t, $J=7.5 \mathrm{~Hz}, 8-2 \mathrm{H}), 2.69-2.82$ (m, 5", 8", 5*, $8 *-8 \mathrm{H}), 2.86(\mathrm{~d}, J=20.7 \mathrm{~Hz}, 10 \mathrm{ax}-1 \mathrm{H}), 3.21$ (dd, $J=$ $19.2 \mathrm{~Hz}, J=1.2 \mathrm{~Hz}, 10 \mathrm{eq}-1 \mathrm{H}), 3.64$ (bs, 4'-1H), 4.03 (s, $\left.\mathrm{OCH}_{3}-3 \mathrm{H}\right), 4.11-4.27\left(\mathrm{~m}, 3^{\prime}-1 \mathrm{H}, 5^{\prime}-1 \mathrm{H}\right), 4.56$ (s, 9-OH$1 \mathrm{H}), 5.08(\mathrm{~d}, J=18.3 \mathrm{~Hz}, 14-1 \mathrm{H}), 5.18-5.21(\mathrm{~m}, 7-1 \mathrm{H})$, 5.29-5.46 (m, 3", 4", 6", 7", 9", 10", 3*, 4*, 6*, 7*, 9*, 10*_ $12 \mathrm{H}), 5.32$ (d, $J=18.0 \mathrm{~Hz}, 14-1 \mathrm{H}), 5.45$ (d, $J=3.3 \mathrm{~Hz}, 1^{\prime}-$ $1 \mathrm{H}), 5.88\left(\mathrm{~d}, J=8.4 \mathrm{~Hz}, 4^{\prime}-\mathrm{OH}-1 \mathrm{H}\right), 7.35(\mathrm{dd}, J=8.7 \mathrm{~Hz}$, $J=1.2 \mathrm{~Hz}, 3-1 \mathrm{H}), 7.75(\mathrm{dd}, J=7.8 \mathrm{~Hz}, J=0.6 \mathrm{~Hz}, 1-1 \mathrm{H})$, $7.98(\mathrm{dd}, J=7.8 \mathrm{~Hz}, J=1.2 \mathrm{~Hz}, 2-1 \mathrm{H}), 13.12$ (s, 6-OH1H), 13.91 (s-11-OH-1H). ${ }^{13} \mathrm{C} \mathrm{NMR}\left(\mathrm{CDCl}_{3}, 75 \mathrm{MHz}\right) \delta$ (ppm): $14.2\left(\mathrm{C}-1^{\prime \prime}, 1^{*}\right), 16.8\left(\mathrm{C}-6^{\prime}\right), 20.5\left(\mathrm{C}-2^{\prime \prime}, 2^{*}\right), 25.5$ $\left(\mathrm{C}-5^{\prime \prime}\right), 25.5\left(\mathrm{C}-5^{*}, 8^{\prime \prime}\right), 25.6\left(\mathrm{C}-8^{*}\right), 25.6\left(\mathrm{C}-16^{\prime \prime}\right), 25.6(\mathrm{C}-$ 16*), $27.1\left(\mathrm{C}-11^{\prime \prime}\right), 27.2$ (C-11*), 29.0 (C-15"), 29.1 (C15*), 29.1 (C-14"), 29.2 (C-14*, 13"), 29.2 (C13*), 29.5 (C-12"), $29.6\left(\mathrm{C}-12^{*}\right), 29.9$ (C-2'), 33.9 (C-21"), 35.4 (C10), 36.7 (C-8), $45.1\left(\mathrm{C}-3^{\prime}\right), 56.6\left(\mathrm{C}-O C H_{3}\right), 65.9(\mathrm{C}-14)$, $67.2\left(\mathrm{C}^{\prime} 5^{\prime}\right), 69.6\left(\mathrm{C}^{\prime} 4^{\prime}\right), 69.8(\mathrm{C}-7), 77.1$ (C-9), $100.7(\mathrm{C}-$ $1^{\prime}$ ), 111.2 (C-5a), 111.3 (C-11a), 118.4 (C-3), 119.7 (C-1), 120.6 (C-4a), $127.0\left(\mathrm{C}-4^{\prime \prime}\right), 127.1\left(\mathrm{C}-4^{*}\right), 127.6\left(\mathrm{C}-6^{\prime \prime}\right)$, $127.7\left(\mathrm{C}-6^{*}\right), 128.2\left(\mathrm{C}-9^{\prime \prime}\right), 128.2\left(\mathrm{C}-7^{\prime \prime}, 7^{*}, 9^{*}\right), 130.2(\mathrm{C}-$ $\left.10^{\prime \prime}\right), 130.3$ (C-10*), 131.9 (C-3", 3*), 133.6 (C-10a), 133.9 (C-12a), 135.3 (C-6a), 135.7 (C-2), 155.6 (C-11), 156.2 (C6), 160.9 (C-4), 172.4 (C-22"), 173.1 (C-22*), 186.4 (C12), 186.8 (C-5), 206.7 (C-13).

HRMS (ESI) m/z 1086.5883 (calcd for $\mathrm{C}_{63} \mathrm{H}_{85} \mathrm{NO}_{13} \mathrm{Na}$ $\left.[\mathrm{M}+\mathrm{Na}]^{+}, 1086.5919\right)$.

\section{Doxorubicin DHA acid amide/ester (5)}

Red solidifying oil, $75 \mathrm{mg}(37 \%) .[\alpha]_{\mathrm{D}}^{23}=+138.2(c 0.5$, $\mathrm{CH}_{2} \mathrm{Cl}_{2}$ ).

${ }^{1} \mathrm{H} \mathrm{NMR}\left(\mathrm{CDCl}_{3}, 300 \mathrm{MHz}\right) \delta(\mathrm{ppm}): 0.96(\mathrm{t}, J=7.5 \mathrm{~Hz}$, $\left.1^{\prime \prime}-3 \mathrm{H}\right), 0.97$ (t, $\left.J=7.5 \mathrm{~Hz}, 1^{*}-3 \mathrm{H}\right), 1.32\left(\mathrm{~d}, J=6.3 \mathrm{~Hz}, 6^{\prime}-\right.$ $3 \mathrm{H}), 1.70-1.80\left(\mathrm{~m}, 2^{\prime}-2 \mathrm{H}\right), 2.01-2.10$ (m, 21", 21*-4H), 
2.12-2.21 (m, 2", 20"-4H), 2.32-2.39 (m, 8-2H), 2.44-2.53 $\left(\mathrm{m}, 2^{*}, 20^{*}-4 \mathrm{H}\right), 2.78-2.86\left(\mathrm{~m}, 5^{\prime \prime}, 8^{\prime \prime}, 11^{\prime \prime}, 14^{\prime \prime}, 17^{\prime \prime}, 5^{*}\right.$, $\left.8^{*}, 11^{*}, 14^{*}, 17^{*}-20 \mathrm{H}\right), 2.95(\mathrm{~d}, J=18.9 \mathrm{~Hz}, 10 \mathrm{ax}-1 \mathrm{H})$, $3.26(\mathrm{dd}, J=18.9 \mathrm{~Hz}, J=1.5 \mathrm{~Hz}, 10 \mathrm{eq}-1 \mathrm{H}), 3.64$ (d, $J=$ $\left.5.7 \mathrm{~Hz}, 4^{\prime}-1 \mathrm{H}\right), 4.06\left(\mathrm{~s}, \mathrm{OCH}_{3}-3 \mathrm{H}\right), 4.11-4.18\left(\mathrm{~m}, 3^{\prime}-1 \mathrm{H}\right.$, 5'-1H), 4.19-4.25 (m, 14-1H), 4.57 (s, 9-OH-1H), 5.10 (d, $J=18.3 \mathrm{~Hz}, 14-1 \mathrm{H}), 5.25-5.27(\mathrm{~m}, 7-1 \mathrm{H}), 5.29-5.46(\mathrm{~m}$, $3^{\prime \prime}, 4^{\prime \prime}, 6^{\prime \prime}, 7^{\prime \prime}, 9^{\prime \prime}, 10^{\prime \prime}, 12^{\prime \prime}, 13^{\prime \prime}, 15^{\prime \prime}, 16^{\prime \prime}, 18^{\prime \prime}, 19^{\prime \prime}, 3^{*}, 4^{*}$, $\left.6^{*}, 7^{*}, 9^{*}, 10^{*}, 12^{*}, 13^{*}, 15^{*}, 16^{*}, 18^{*}, 19^{*}-24 \mathrm{H}\right), 5.49$ (d, $\left.J=3.6 \mathrm{~Hz}, 1^{\prime}-1 \mathrm{H}\right), 5.85\left(\mathrm{~d}, J=8.4 \mathrm{~Hz}, 4^{\prime}-\mathrm{OH}-1 \mathrm{H}\right), 7.38$ $(\mathrm{dd}, J=8.7 \mathrm{~Hz}, J=1.2 \mathrm{~Hz}, 3-1 \mathrm{H}), 7.77(\mathrm{dd}, J=7.5 \mathrm{~Hz}$, $J=0.9 \mathrm{~Hz}, 1-1 \mathrm{H}), 8.02(\mathrm{dd}, J=7.5 \mathrm{~Hz}, J=1.2 \mathrm{~Hz}, 2-1 \mathrm{H})$, 13.19 (s, 6-OH-1H), 13.95 (s-11-OH-1H). ${ }^{13} \mathrm{C} \quad \mathrm{NMR}$ $\left(\mathrm{CDCl}_{3}, 75 \mathrm{MHz}\right) \delta(\mathrm{ppm}): 14.3\left(\mathrm{C}-1^{\prime \prime}, 1^{*}\right), 16.7\left(\mathrm{C}-6^{\prime}\right)$, $20.5\left(\mathrm{C}-2^{\prime \prime}, 2^{*}\right), 23.3$ (C-20", 20*), 25.3 (C-5", 5*), $25.6(\mathrm{C}-$ $\left.8^{\prime \prime}, 8^{*}, 11^{\prime \prime}, 11^{*}, 14^{\prime \prime}, 14^{*}\right), 25.6\left(\mathrm{C}-17^{\prime \prime}, 17^{*}\right), 30.0\left(\mathrm{C}-2^{\prime}\right)$, $33.6\left(\mathrm{C}-21^{*}\right), 33.8\left(\mathrm{C}-21^{\prime \prime}\right), 35.5$ (C-10), 36.4 (C-8), 45.2 $\left(\mathrm{C}-3^{\prime}\right), 56.6\left(\mathrm{C}-\mathrm{OCH}_{3}\right), 66.0(\mathrm{C}-14), 67.2\left(\mathrm{C}-5^{\prime}\right), 69.6(\mathrm{C}-$ 4'), 69.8 (C-7), 77.2 (C-9), 100.7 (C-1'), 111.3 (C-5a), 111.5 (C-11a), 118.4 (C-3), 119.8 (C-1), 120.8 (C-4a), $127.0\left(\mathrm{C}-4^{\prime \prime}\right), 127.0\left(\mathrm{C}-4^{*}\right), 127.8\left(\mathrm{C}-6^{\prime \prime}\right), 127.8\left(\mathrm{C}-6^{*}\right)$, 127.9 (C-7*), 128.0 (C-7"), 128.0 (C-9"), 128.0 (C-9*), 128.1 (C-10", 10*), 128.1 (C-12"), 128.2 (C-12*), 128.2 (C-13"), 128.2 (C-13*, 15", 15*, 16", 16*), 128.5 (C-18", $\left.18^{*}\right), 129.2$ (C-19*), 129.3 (C-19"), 132.0 (C-3", 3*), 133.6 (C-10a), 133.9 (C-12a), 135.5 (C-6a), 135.7 (C-2), 155.7 (C-11), 156.2 (C-6), 161.0 (C-4), 171.6 (C-22"), 172.4 (C22*), 186.5 (C-12), 187.0 (C-5), 206.6 (C-13).

HRMS (ESI) m/z 1186.6279 (calcd for $\mathrm{C}_{71} \mathrm{H}_{89} \mathrm{NO}_{13} \mathrm{Na}$ $\left.[\mathrm{M}+\mathrm{Na}]^{+}, 1186.6232\right)$.

\section{Cell cultures}

The human primary (SW480), metastatic (SW620) colon cancer, and human metastatic prostate cancer cell lines (PC3) were obtained from the American Type Culture Collection and Chinese hamster lung fibroblasts (V79) were supplied by Prof. M.Z. Zdzienicka (Leiden University Medical Centre, Leiden. The Netherlands). The cells were seeded in medium recommended by manufactures (MEM for SW480 and SW620, RPMI 1640 for PC3 and F10 Ham's for V79) supplemented with $10 \% \mathrm{FBS}$, penicillin $(100 \mathrm{U} / \mathrm{mL})$ and streptomycin $(100 \mu \mathrm{g} / \mathrm{mL})$ and cultured in $37{ }^{\circ} \mathrm{C} / 5 \% \quad \mathrm{CO}_{2}$ humidified incubator. After reaching 80-90\% confluence cells were passaged using trypsinEDTA and seeded in 96-well plates $\left(1 \times 10^{4}\right.$ cells per well) for MTT assay. Next, to determine $\mathrm{IC}_{50}$ the cells were treated for $72 \mathrm{~h}$ with different concentrations of DOX, DOX conjugates with LNA and/or DHA (2 - DOXmonoLNA, 4 - DOX-diLNA, 3 - DOX-monoDHA, 5 DOX-diDHA), and the mixture of DOX and LNA or DHA. Cells without studied compounds in medium were used as a control.

\section{Cell viability assessment by MTT assay}

The cell viability was assessed by determination of MTT salt [3-(4,5-dimethylthiazol-2-yl)-2,5-diphenyltetrazolium bromide] conversion by mitochondrial dehydrogenase. MTT assay was performed as previously described (Mielczarek-Puta M et al. 2019). After 72 h treatment with different concentration of tested compounds the cells were incubated at $37^{\circ} \mathrm{C}$ for $4 \mathrm{~h}$ with MTT solution $(0.5 \mathrm{mg} / \mathrm{mL})$, which in viable cells is converted to insoluble formazan by mitochondrial dehydrogenase. Next, obtained purple product was dissolved in DMSO and isopropanol (1:1). Optical density of the solution of each well was measured at $570 \mathrm{~nm}$ using UVM 340 reader (ASYS Hitech GmbH, Austria). Experiments were repeated three times.

Cell viability was presented as a percent of MTT reduction in the treated cells versus the control cells. Number of viable cells cultured without studied compounds was assumed as $100 \%$. Decreased relative MTT level indicates decreased cell viability.

\section{LDH assay}

Release of lactate dehydrogenase (LDH) from the cytosol to culture medium (cellular membrane integrity assessment) is a marker of cell death. The LDH activity was performed after $72 \mathrm{~h}$ incubation of cells $\left(1 \times 10^{4}\right.$ cells per well $)$ in 96well plates with studied compounds according to manufacturer's protocol (Roche Diagnostics, Germany) as was described by Jóźwiak et al. (Jóźwiak et al. 2019). The LDH activity was determined in harvested medium incubated with the reaction mixture for $30 \mathrm{~min}$ at room temperature. An absorbance was measured at $490 \mathrm{~nm}$ using UVM 340 reader (ASYS Hitech $\mathrm{GmbH}$, Austria). Compound mediated cytotoxicity was determined by the following equation: [(A test sample - A low control)/(A high control - A low control)] $\times 100 \%$ (A-absorbance); where "low control" were cells in medium with $2 \%$ FBS without tested compounds and "high control" were cells incubated in medium with $2 \%$ FBS and $1 \%$ Triton X-100 (100\% LDH release). The cytotoxicity was expressed as percentage $\mathrm{LDH}$ release as compared with the maximum release of LDH from TritonX100-treated cells.

\section{Annexin $\mathrm{V}$ binding assay}

The cells were cultured and harvested under the conditions mentioned in the cell culture section, seeded in sixwell plates $\left(2 \times 10^{5}\right.$ cells per well $)$, and treated with tested compounds at their $\mathrm{IC}_{50}$ concentration for $72 \mathrm{~h}$. The effect of cell exposure to compounds was determined as described previously (Mielczarek-Puta et al. 2019) by dual staining with Annexin V:FITC and propidium iodide 
(PI), according to manufacturer's protocol (Becton Dickinson) and analyzed by flow cytometry (Becton Dickinson). After $72 \mathrm{~h}$ incubation both floating and adherent cells were harvested. The floating cells were collected by centrifugation at $700 \times g$ for $5 \mathrm{~min}$ at $4{ }^{\circ} \mathrm{C}$. Adherent cells were first trypsinized and then collected by centrifugation at $700 \times g$ for $5 \mathrm{~min}$ at $4{ }^{\circ} \mathrm{C}$. Both fractions were resuspended in Annexin $\mathrm{V}$ binding buffer, pooled and incubated with FITC Annexin V and PI for $15 \mathrm{~min}$ at room temperature in the dark. The cells which were Annexin V: FITC positive and PI negative were identified as early apoptotic, and Annexin V:FITC and PI positive as late apoptotic or necrotic.

\section{Statistical analysis}

The statistical calculation was performed using Statistica 12.0 (StatSoft, Inc, USA) program. Quantitative comparisons were made using Student's $t$-test. $\mathrm{IC}_{50}$ value was estimated by CompuSyn version 1.0. All presented experiments were repeated at least three times, the results were expressed as the means \pm SD and considered statistically significant at $P<0.05$.

\section{Results and discussion}

The structure of DOX can be modified in at least three ways:

(1) By fixing the amide bond in the reaction of the primary amine group (NH2) in the $\left(\mathrm{C}-3^{\prime}\right)$ position (Meng-lei et al. 2009; Huan et al. 2009; Bhupender et al. 2011; Liang 2014; Piorecka et al. 2017)

(2) By creating a hydrazone linker in the reaction of a carbonyl group $(\mathrm{C}=\mathrm{O})$ in the $(\mathrm{C}-13)$ position (Willner et al. 1993; Wang et al. 2006; Liang 2014)

(3) By forming an ester bond by a hydroxyl group $(\mathrm{OH})$ in the (C-14) position (Arcamone et al. 1974).

In our work, we obtained amide derivatives by reaction of the amino group with LNA and DHA $(\mathbf{2}, \mathbf{3})$, as well as double-substituted derivatives via amide and ester linkages $(4,5)$.

The method of obtaining amides is a slightly modification of the method used by Piórecka et al. (Piorecka et al. 2017), presented in Scheme 1. The reagent proportions and reaction temperature have been changed.

The corresponding amide (2-DOX-monoLNA, 3DOX-monoDHA) was obtained by the reaction of DOX with acids (LNA, DHA) in a stoichiometric ratio of DOX. When we used an excess of acids (LNA, DHA) in relation to DOX, we obtained double substituted products, with an amide and ester linkage (4-DOX-diLNA, 5-DOXdiDHA).

The synthesis was carried out under room temperature under slightly modified conditions described by Piórecka. To a solution of carboxylic acid (LNA or DHA) and $\mathrm{N}, \mathrm{N}^{\prime}$-dicyclohexylcarbodiimide (DCC) in solvent mixtures of $\mathrm{CH}_{2} \mathrm{Cl}_{2} / \mathrm{DMF}$ 4-(dimethylamino)pyridine (DMAP) and DOX hydrochloride (DOX $\cdot \mathrm{HCl})$ were added and the resulting suspension was stirred for $20 \mathrm{~h}$ in the dark. The product was isolated using column chromatography on silica gel and $\mathrm{CH}_{2} \mathrm{Cl}_{2}$ : $\mathrm{MeOH}$ mixture as an eluent.

DOX conjugates with LNA and DHA (2-DOX-monoLNA, 3-DOX-monoDHA) formed only by an amide link were obtained previously (Liang 2014; Huan et al. 2009). The conjugates generated by the amide and ester linkages are new compounds.

\section{Biological studies}

\section{Cytotoxic activity}

The aim of this study was to evaluate cytostatic activity of mono (2-DOX-monoLNA, 3-DOX-monoDHA) and di (4-DOX-diLNA, 5-DOX-diDHA) DOX conjugates and compare their activity with DOX and mixture of DOX and LNA or DHA. Cells viability measured by MTT assay was determined in human cancer cell lines (SW480, SW620, and PC3) and Chinese hamster lung fibroblasts (V79) that were used as a control. The cytotoxic activity was established by calculation of the inhibitory concentration $\mathrm{IC}_{50}$ (Neubig et al. 2003). In addition, a cytotoxic capacity against tumor cells for tested compounds was expressed as a selectivity factor (selectivity index, SI).

All studied compounds (conjugates, mixture of DOX and LNA or DHA and DOX) were more cytotoxic against cancer than normal cells. The $\mathrm{IC}_{50}$ values determined for V79 cells was about tenfold higher as compared with all studied cancer (SW480, SW620, and PC3) cell lines. While the mixture of DOX with LNA or DHA and DOX showed fivefold higher cytotoxicity against cancer cells and even 15-fold higher against normal cells in comparison to all DOX conjugates (Table 1).

DOX conjugates with fatty acids showed lower cytotoxicity compared with DOX mixes with fatty acids and DOX against all tumor cell lines. This result is compensated by significantly lower cytotoxicity to the normal cell line, SI ranged from 5.78 to 30.85 (Table 1).

The cytotoxic potential of DOX conjugated by amide bond with LNA (DOX-ami-LNA and hydrazone bond (DOX-hyd-LNA) was previously studied (Liang 2014; Huan et al. 2009) in hepatocellular carcinoma and breast cancer. According to the data described by Liang et al. conducted on cancer (HepG2, MCF-7, MDA-MB-231) and 
<smiles>COc1cccc2c1C(=O)c1c(O)c3c(c(O)c1C2=O)C[C@@](O)(C(=O)CO)C[C@H]3OC1=C[C@H](N)[C@@H](O)[C@H](C)O1</smiles>

1 eqv $\mathrm{RCOOH}$

DCC,DMAP

$\mathrm{CH}_{2} \mathrm{Cl}_{2}$ :DMF, 9:1

rt

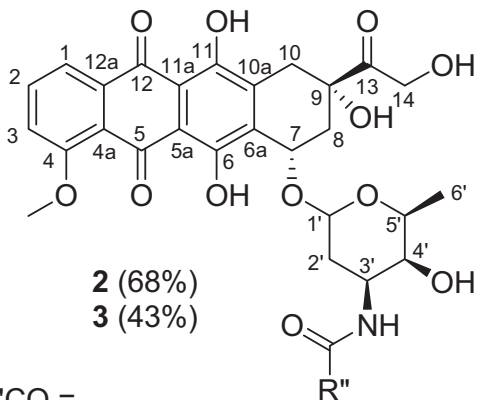

2, $\mathrm{R} " \mathrm{CO}=$

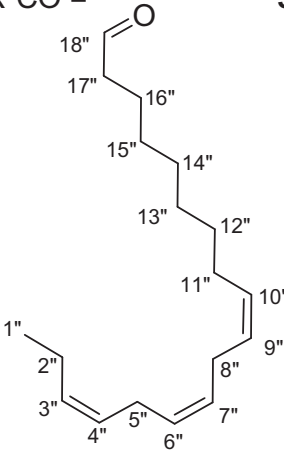

3, $\mathrm{R} " \mathrm{CO}=$

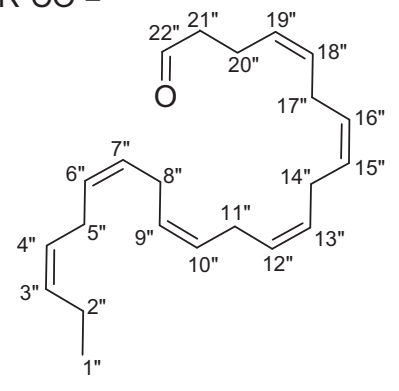<smiles>COc1cccc2c1C(=O)c1c(O)c3c(c(O)c1C2=O)C[C@@](O)(C(=O)CO)C[C@H]3OC1=C[C@@H](N)[C@H](O)[C@H](C)O1</smiles>

4, R"CO =

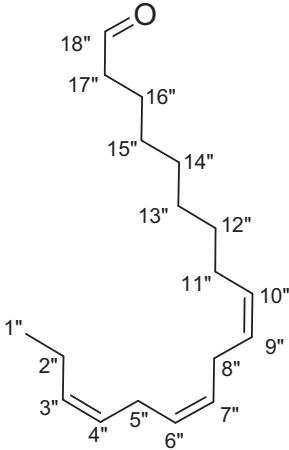

$4, \mathrm{R}^{*} \mathrm{CO}=$

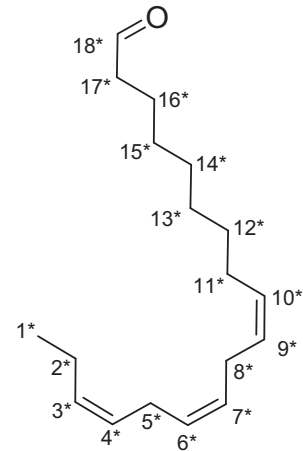

Scheme 1 Synthesis of doxorubicin conjugates

normal (HUVEC) cells DOX-ami-LNA expressed higher cytotoxic potential to cancer than normal cells, but antitumor activity was about threefold lower in comparison to DOX-hyd-LNA. The highest toxic effect of DOX-hyd-LNA was explained by its better stability in serum increasing drug distribution and its release to the tumor cell. Similar to our results both DOX-LNA conjugates exhibited higher SI
$(>5)$ than DOX $(<2)$ what indicated that they had higher cytoprotection (Liang 2014). Interestingly, Huan et al. demonstrated threefold higher cytotoxicity of DOX-amidLNA against MDA-MB-231 cells and twofold against HepG2 and MCF-7 as compared with DOX. Moreover, authors suggested that conjugation of DOX with LNA increased bioavailability of whole complex and its 
Table 1 Cytotoxic activity of tested compounds

\begin{tabular}{|c|c|c|c|c|c|c|c|}
\hline \multirow[t]{3}{*}{ Compound } & \multicolumn{6}{|l|}{ Cancer cells } & \multirow{3}{*}{$\begin{array}{l}\text { Normal cells } \\
\text { V } 79 \\
\text { IC }_{50}\end{array}$} \\
\hline & \multicolumn{2}{|l|}{ SW480 } & \multicolumn{2}{|l|}{ SW 620} & \multicolumn{2}{|l|}{ PC3 } & \\
\hline & $\mathrm{IC}_{50}$ & SI & $\mathrm{IC}_{50}$ & SI & $\mathrm{IC}_{50}$ & SI & \\
\hline 2 (DOX-monoLNA) & $1.94 \pm 0.11$ & 8.07 & $2.43 \pm 0.08$ & 6.44 & $1.23 \pm 0.19$ & 12.73 & $15.66 \pm 1.38$ \\
\hline 4 (DOX-diLNA) & $2.09 \pm 0.24$ & 17.12 & $2.62 \pm 0.37$ & 13.66 & $1.16 \pm 0.20$ & 30.85 & $35.79 \pm 0.10$ \\
\hline 3 (DOX-monoDHA) & $2.22 \pm 0.12$ & 7.70 & $1.4 \pm 0.02$ & 12.22 & $1.27 \pm 0.17$ & 13.47 & $17.11 \pm 0.75$ \\
\hline 5 (DOX-diDHA) & $2.20 \pm 0.09$ & 8.61 & $1.64 \pm 0.03$ & 11.55 & $3.28 \pm 1.74$ & 5.78 & $18.95 \pm 2.03$ \\
\hline DOX, LNA (mixture) & $0.26 \pm 0.07$ & 8.73 & $0.32 \pm 0.05$ & 7.09 & $0.36 \pm 0.06$ & 6.30 & $2.27 \pm 1.81$ \\
\hline DOX, DHA (mixture) & $0.53 \pm 0.12$ & 4.84 & $0.31 \pm 0.06$ & 8.29 & $0.22 \pm 0.04$ & 11.68 & $2.57 \pm 0.51$ \\
\hline Doxorubicin (DOX) & $0.29 \pm 0.08$ & 6.93 & $0.31 \pm 0.08$ & 6.48 & $0.59 \pm 0.02$ & 3.4 & $2.01 \pm 0.03$ \\
\hline
\end{tabular}

Data are given as $\mathrm{IC}_{50}[\mu \mathrm{M}]$ and SI. The $\mathrm{IC}_{50}$ is defined as the concentration of the compound that corresponds to a $50 \%$ growth inhibition. Chinese hamster lung fibroblasts (V79), human primary colon cancer cells (SW480), human metastatic colon cancer cells (SW620), and human metastatic prostate cancer cells (PC3). Data are expressed as mean \pm SD. The SI (selectivity index) was calculated for each compounds using formula: $\mathrm{SI}=\mathrm{IC}_{50}$ for normal cell line/ $\mathrm{IC}_{50}$ cancer cell line internalization by cancer cells. Obtained results exhibited more efficient uptake of DOX-amid-LNA conjugates than DOX, therefore the authors stated that LNA may be useful as a DOX carrier to enhance anti-tumor action of DOX (Huan et al. 2009).

Our resulted indicated that DOX-diLNA exhibited the most effective toxic potential (4), its $\mathrm{IC}_{50}$ values against cancer cells were similar to the rest of conjugates but its SI factor was the highest from all studied compounds (17.12 for SW480; 13.66 for SW620 and 30.85 for PC3). The obtained data suggested that conjugate DOX-diLNA (4) is markedly less active against normal cells, therefore may be of interest for further studies on anticancer agent. Reference data demonstrated that drug delivery systems based on the dietary $\omega-3$ fatty acids (DHA, EPA, and LNA) resulted in increased sensitivity to chemotherapy, especially for drug resistant cancer cells. Moreover, in many cases lipid-drug conjugates increased cytotoxicity to tumor cells simultaneously protecting normal cells (Huan et al. 2009).

In contrast, the SI of DOX in all cancer cell lines was lower than for DOX conjugates and similar to SI for the mixture of DOX and unsaturated fatty acid. The strongest differences between DOX and its mixes were observed in PC3 cells. The $\mathrm{IC}_{50}$ values for mixture of DOX and LNA/ DHA was about twofold lower than DOX, whereas the SI factor increased from 3.4 for DOX to 6.3 for DOX, LNA mixture and even to 11.68 for DOX, DHA mixture.

Besides inhibition of topoisomerase II activity, the antitumor effect of DOX is based on the generation of large amounts of ROS what lead to the cell membrane lipid peroxidation. It is known that PUFAs enhance the DOX activity against breast cancer cell lines (Maheo et al. 2005; Germaini et al. 1998). An independent study showed that DHA increased the DOX cytotoxicity against MDA-MB-
231 (DOX sensitive) and MCF-7dox (DOX-resistant) cell lines in comparison to MCF-7 (dox sensitive). The authors noticed that DHA supplementation led to the rise of membrane phospholipid DHA level, without changes in intracellular DOX concentration. Therefore these cells were more susceptible for oxidative stress caused by DOX. According to Zajdel et al. tumoricidal DOX action is selective and depends on PUFAs concentration and type of cancer. They demonstrated that DHA in high concentration $(100 \mu \mathrm{M})$ enhanced DOX cytotoxicity against human glioma cell lines (8-MG-BA, 42-MG-BA), whereas glioblastoma cell line (SNB-19) remained resistant to PUFAs. However, lower DHA concentration $(25 \mu \mathrm{M})$ decreased DOX toxicity in SNB-19 cells. Similar effect was observed for LNA $(25 \mu \mathrm{M})$ in glioma cells (8-MG-BA) (Zajdel et al. 2010). In current work we showed that DHA and LNA altered DOX cytotoxic effect in metastatic PC3 cells but not in metastatic SW620 cells. It indicated that PUFAs selective tumoricidal action can influence on sensitivity of cancer cells to chemotherapy. In turn, experimental study conducted on DOX-resistant and DOX-sensitive small-cell lung carcinoma cells revealed that preincubation with DHA led to the increase in phospholipid DHA concentration without the loss of cell viability. Interestingly, only the DOXresistant cells exhibited higher DOX sensitivity (Huan et al. 2009).

The clinical use of DOX is limited by its cardiotoxicity, which is mediated through different mechanisms e.g., membrane lipid peroxidation in the endoplasmic reticulum. The damage of membrane impairs desaturation and elongation of linoleic (LA) and LNA resulting in cellular PUFAs deficit, what can lead to heart cell damage (Bordoni et al. 1999). Results presented in the current work showed that DOX conjugates had strong anticancer effect but higher SI in comparison to DOX. It indicated that studied DOX 
conjugates were as effective as DOX but they cytotoxicity toward normal cell was much lower than DOX alone.

To estimate the influence of DOX conjugates (2-5) and DOX on normal cells viability in a period of time, the V79 cells were treated with tested compounds for 24,48 , and $72 \mathrm{~h}$ (Fig. 1). The study revealed that the cytotoxic effect of all compounds was time dependent and differed between conjugates. The viability of V79 cells rapidly decreased after $48 \mathrm{~h}$ incubation with DOX-diDHA (5), from $\mathrm{IC}_{50}$ values $202.22 \pm 6.83 \mu \mathrm{M}$ after $24 \mathrm{~h}$ treatment to $24.47 \pm$ $2.24 \mu \mathrm{M}$ after $48 \mathrm{~h}$ incubation. Similar results were observed for the remaining compounds. The $\mathrm{IC}_{50}$ of compounds 2 and 4 decreased from $34.87 \pm 2.34$ and $146.11 \pm$ $5.65 \mu \mathrm{M}$ after $24 \mathrm{~h}$ to $16.33 \pm 1.18$ and $87.77 \pm 3.43 \mu \mathrm{M}$ after $48 \mathrm{~h}$ incubation, respectively. The $\mathrm{IC}_{50}$ value for compound 3 after $24 \mathrm{~h}$ treatment was $43.88 \pm 3.43 \mu \mathrm{M}$ and decreased to $30.37 \pm 1.98 \mu \mathrm{M}$ after $48 \mathrm{~h}$, while for DOX was $16.71 \pm 1.56 \mu \mathrm{M}$ and decreased to $6.82 \pm 1.05 \mu \mathrm{M}$. The lowest viability observed after $72 \mathrm{~h}$ incubation indicates that effect develops in time but cytotoxic activity against normal cells was still significantly lower than in cancer cells.

LDH assay (marker of cell death) was performed on both cancer and normal cell lines for all studied compounds (conjugates, the mixtures, and DOX) at their the highest cytotoxic activity (Fig. 2). The DOX conjugates (2-5) used in concentrations 1,3 , and $5 \mu \mathrm{M}$ expressed concentrationdependent antitumor activity against all cancer cell lines. The percentage of released LDH from all cancer cells was the lowest at $1 \mu \mathrm{M}$ and ranged from 22 to $62 \%$, increased at $3 \mu \mathrm{M}$ to the range of $31-88 \%$, and resulted in the range of $50-88 \%$ at $5 \mu \mathrm{M}$ concentration of the compounds (Fig. 2a).

The cytotoxic effect against V79 cells also depends on conjugates concentration but was observed only at their higher concentrations $(10,20$, and $30 \mu \mathrm{M}$ for compounds $\mathbf{2}$, $\mathbf{3}, \mathbf{5}$ ). Because of less sensitivity of V79 cells for DOXdiLNA (4) the assay was performed at 20,30 , and $40 \mu \mathrm{M}$ concentrations (Fig. 2c). The results exhibited that LDH

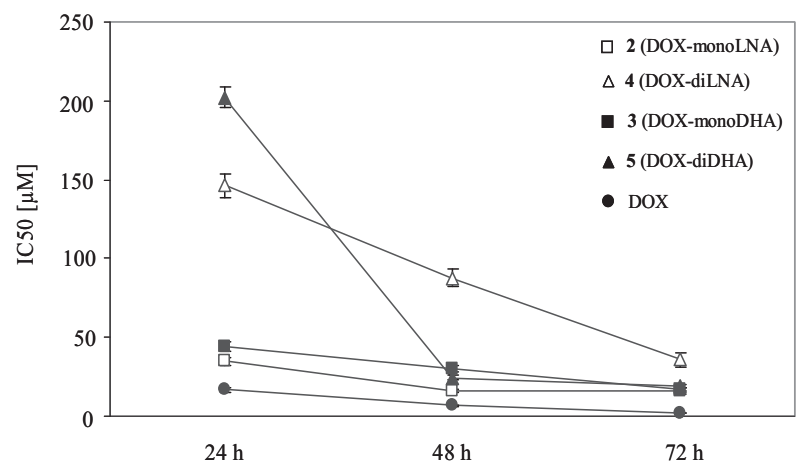

Fig. 1 Cytotoxic activity of doxorubicin and doxorubicin conjugates in the V79 cells, treated for 24,48 , and $72 \mathrm{~h}$. Data are given as $\mathrm{IC}_{50}[\mu \mathrm{M}]$ and expressed as the mean \pm SD from three independent experiments performed in triplicate percentage was similar for all the lowest DOX conjugates concentrations $(10$ or $20 \mu \mathrm{M})$ and resulted in the average $33 \%$. There was no rapid increase of LDH release. At the highest conjugates concentrations ( $30 \mu \mathrm{M}$ for compounds $\mathbf{2}$, $\mathbf{3}, \mathbf{5}$, and $40 \mu \mathrm{M}$ for compound 4 ) the average was $67 \%$, whereas at $20 \mu \mathrm{M}$ (compounds $\mathbf{2 , 3 , 5}$ ) or $30 \mu \mathrm{M}$ (4) the average was $53 \%$ (Fig. 2c). In addition, LDH assay was performed in V79 cells at $5 \mu \mathrm{M}$ concentration of DOX conjugates (2-5) but LDH percentage was significantly lower compared with cancer cells and did not exceed $28 \%$ (Fig. 2a).

The cancer and normal cells with the highest cytotoxic activity of DOX and its mixture with LNA or DHA (0.4, 0.8 , and $1.5 \mu \mathrm{M})$ also released $\mathrm{LDH}$ in concentrationdependent manner (Fig. 2b). It was observed that the LDH percentage for DOX at $0.4 \mu \mathrm{M}$ in all cancer cell lines was from 43 to $62 \%$. At 0.8 and $1.5 \mu \mathrm{M}$ of DOX the $\mathrm{LDH}$ percentage for all cancer cells was $57-67 \%$ and $70-98 \%$, respectively. The $\mathrm{LDH}$ percentage in all cancer cell lines for mixture of DOX and unsaturated fatty acid (LNA or DHA) ranged from 32 to $63 \%$ at $0.4,41$ to $69 \%$ at 0.8 , and 59 to $93 \%$ at $1.5 \mu \mathrm{M}$ concentration. Since the V79 cells were less sensitive to both DOX and the mixtures, LDH percentage was significantly lower than in cancer cells. At 0.8 and $1.5 \mu \mathrm{M}$ of DOX, LDH percentage was $19 \%$ and $50 \%$, respectively. In turn, at 0.8 and $1.5 \mu \mathrm{M}$ concentration of both mixtures average LDH percent counted $14 \%$ and $29 \%$, respectively. In V79 cells, the LDH assay was additionally performed at $3 \mu \mathrm{M}$ concentration of DOX and its mixtures resulting in the highest $\mathrm{LDH}$ percentage $(69 \%$ for DOX, $58 \%$ for DOX, LNA, and $61 \%$ for DOX, DHA) (data not shown).

The LDH assay indicates that cytotoxic effect of all studied compounds increases with rising compounds concentration and are in agreement with data from MTT test. The results obtained for V79 cells were significantly lower than in cancer cells for the same DOX conjugates, DOX, and the mixture concentrations, what confirmed that studied compounds are less harmful for normal cells.

\section{Apoptosis}

The mechanism of cytotoxic action of tested compounds was investigated by the flow cytometry. Annexin V-FITC/ IP assay identifies viable, early apoptotic, late apoptotic, and necrotic cells. The studied cell lines were incubated with all tested compounds (DOX conjugates, mixtures, and DOX) with their $\mathrm{IC}_{50}$ values for $72 \mathrm{~h}$ (Fig. 3a-d).

Almost all tested conjugates (2-5) induced late apoptosis in studied cancer cell lines in range of $60-84 \%$ for SW480, 56-77\% for SW620, and 59-83\% for PC3 cells. However, incubation of SW480 cells with compound $\mathbf{5}$ caused mainly early apoptosis (54\%), whereas compound 4 was mainly 
Fig. $2 \mathrm{LDH}$ release as a marker of cell death in the SW480, SW620, PC3, and V79 cells, treated for $72 \mathrm{~h}$ with different concentrations of doxorubicin conjugates (a) doxorubicin and its mixture with LNA and DHA (b). $\mathrm{LDH}$ release as a marker of cell death in the V79 cells treated for $72 \mathrm{~h}$ with higher concentrations of doxorubicin conjugates (c). Data are expressed as the mean $\pm \mathrm{SD}$ from three independent experiments performed in triplicate. $* p<0.05$ as compared with control, $* * p<0.05$ as compared with normal cells (V79)
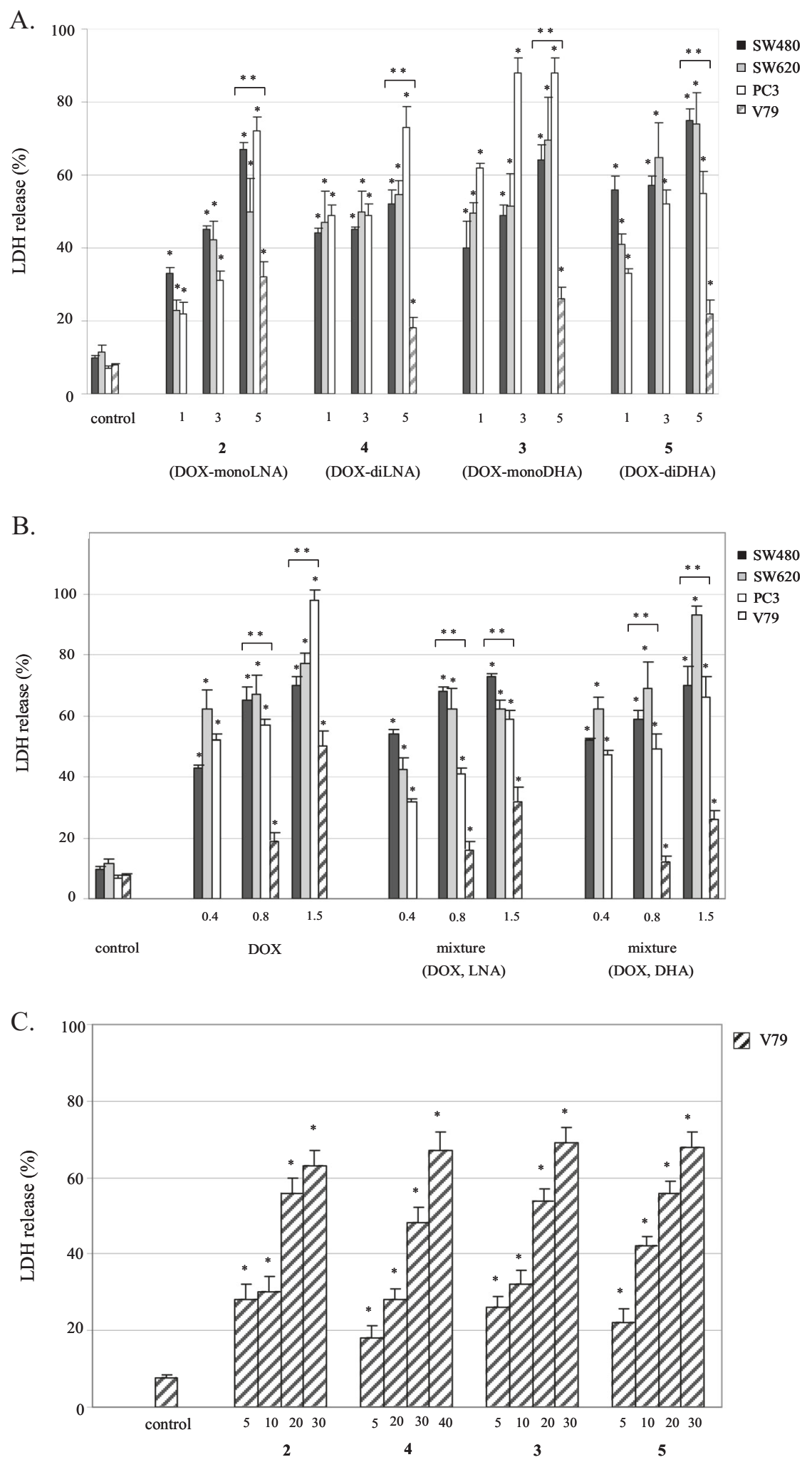

(DOX-monoLNA) (DOX-diLNA) (DOX-monoDHA) (DOX-diDHA) 
Fig. 3 The effect of tested compounds (2-5) late apoptosis in SW480 (a), SW620 (b), PC3 (c), and V79 (d) cells detected with Annexin V-FITC/PI by flow cytometry. Diagrams show representative experiments. The lower right quadrants represent early apoptotic cells. The upper right quadrants contain late stage apoptotic cells or necrotic cells
A. sw480
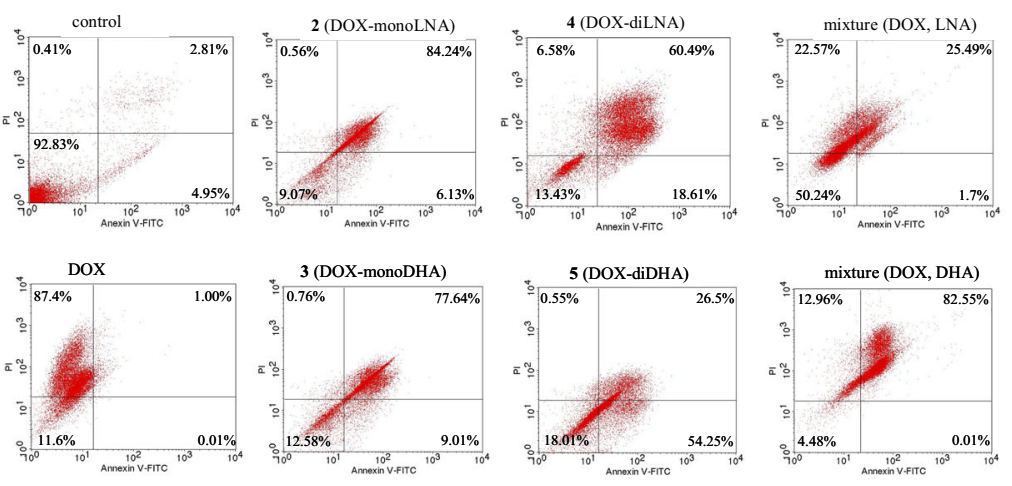

B. $\mathbf{s w 6 2 0}$
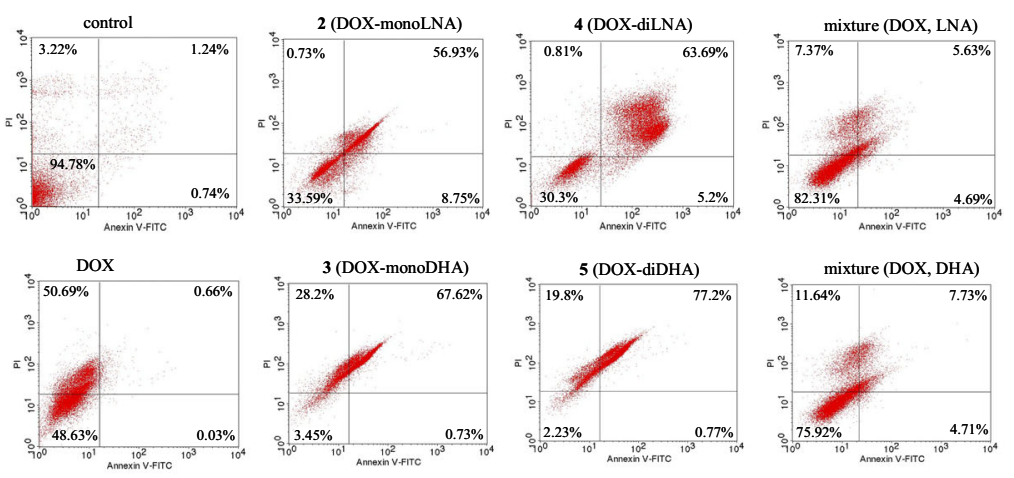

C. $\mathbf{P C}$
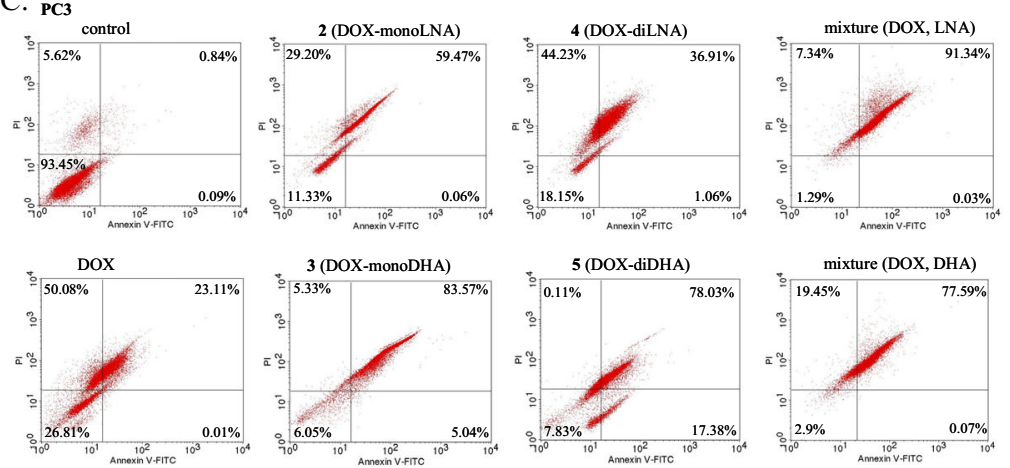

D. $\mathrm{v} 79$
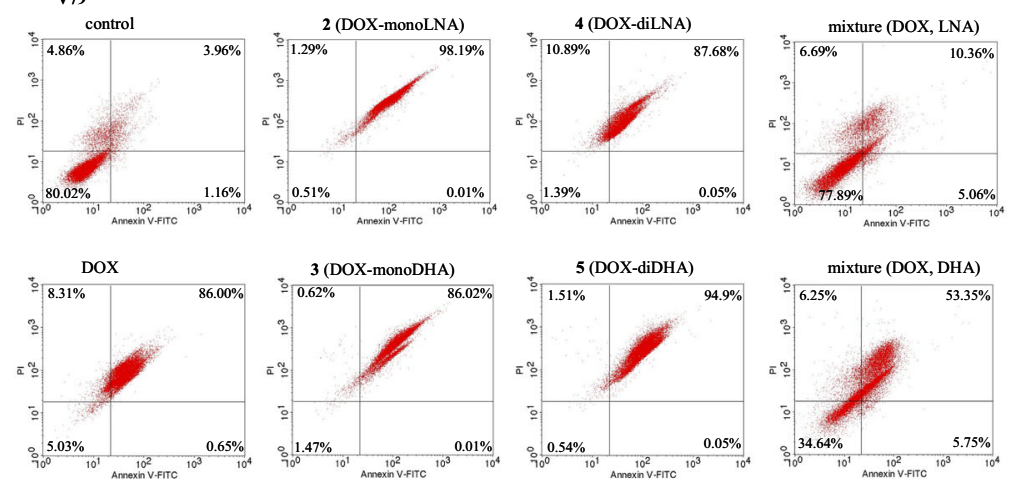
inducer of necrosis (44\%) in PC3 cells. Similar effect was observed for normal V79 cells, where the percentage of cell population in late apoptosis was within the range of 87-98\% for all tested conjugates (2-5).

The treatment of cancer cells with DOX resulted in higher percentage of necrosis (87\% for SW480 and 50\% for SW620 and PC3 cells) as compared with conjugates and V79 cells incubated with DOX, where only $8 \%$ of cells were at necrotic stage. It means that normal cells are less sensitive for DOX what confirmed previously findings from MTT and LDH assays. In opposite to our study, data obtained by Liang et al. revealed that DOX-hyd-LNA in concentration close to $\mathrm{IC}_{50}(1 \mu \mathrm{M})$ did not induced apoptosis. Most cancer cells exhibited late apoptotic stage only at higher conjugate concentration $(10 \mu \mathrm{M})$. Another DOXamid-LNA conjugate demonstrated similar effect. It should be noticed that the experiments were carried only for $24 \mathrm{~h}$ what can indicate that antitumor effect depends not only on dose but also on the time of incubation. In agreement with our findings Liang et al. revealed that DOX $(10 \mu \mathrm{M})$ was stronger inducer of necrosis than DOX conjugates (Liang 2014)

According to our study the mixture of DOX and unsaturated fatty acids did not affect the late apoptosis or necrosis at the same level as the DOX conjugates. We observed viable cancer cells, except high percentage of SW480 cells in late apoptosis (82\%) or necrosis $(25 \%)$ for DOX and DHA and the high percentage of PC 3 cells in the stage of late apoptosis for both mixtures ( $91 \%$ for DOX, LNA and $77 \%$ for DOX, DHA). The high percent of viable V79 cells after incubation with DOX, LNA (77\%) and DOX, DHA (34\%) as compared with DOX (5\%) can suggest that the unsaturated fatty acids protect normal cells against cytotoxic action of DOX. These results indicated that chemosensitivity of cells is selectively modulated by PUFAs, what confirmed data from MTT assay and is in agreement with findings obtained by other authors (Maheo et al. 2005 and Zajdel et al. 2010).

\section{Conclusion}

DOX is a leading cytostatic agent, however serious adverse effects are related to the use of this drug. Therefore, we are still looking for methods that allow us to preserve the therapeutic effect against the tumor cells and reduce the toxicity to the normal cells.

We conclude that all studied compounds (conjugates 25, DOX and mixture of DOX with LNA or DHA) were more cytotoxic against cancer cells than normal cells. However, DOX conjugates showed lower cytotoxicity against all tumor cell lines in comparison to DOX and its mixes with fatty acids. Among the derivatives, the conjugates formed by the amide and ester linkages $(\mathbf{4}, \mathbf{5})$ were found to be more promising compared with conjugates $(2,3)$ formed only by the amide linkage. The most of interest as anticancer agent is DOX-diLNA conjugate (4). Almost all tested conjugates (2-5) induced late apoptosis in studied cancer cell lines. In contrast, the treatment of cancer cells with DOX resulted in higher percentage of necrosis.

Acknowledgements This work was supported by the Medical University of Warsaw and carried out with the use of CePT infrastructure financed by the European Union-the European Regional Development Fund within the Operational Programme Innovative Economy for 2007-2013.

\section{Compliance with ethical standards}

Conflict of interest The authors declare that they have no conflict of interest.

Publisher's note Springer Nature remains neutral with regard to jurisdictional claims in published maps and institutional affiliations.

Open Access This article is distributed under the terms of the Creative Commons Attribution 4.0 International License (http://crea tivecommons.org/licenses/by/4.0/), which permits unrestricted use, distribution, and reproduction in any medium, provided you give appropriate credit to the original author(s) and the source, provide a link to the Creative Commons license, and indicate if changes were made.

\section{References}

Arcamone F, Franceschi G, Mirghetti A, Penco S, Radaelli S (1974) Synthesis and biological evaluation of some 14-o-derivatives of adriamycin. J Med Chem 17:335-337

Bhupender SC, Nicole St J, Deendayal M, Anil K, Keykavous P (2011) Fatty acyl amide derivatives of doxorubicin: synthesis and in vitro anticancer activities. Eur J Med Chem 46:2037-2042

Bielack SS, Erttmann R, Kempf-Bielack B, Winkler K (1996) Impact of scheduling on toxicity and clinical efficacy of doxorubicin: what do we know in the mid-nineties? Eur $\mathrm{J}$ Cancer 32A:1652-1660

Binaschi M, Bigioni M, Cipollone A, Rossi C, Goso C, Maggi CA, Capranico G, Animati F (2001) Anthracyclines: selected new developments. Curr Med Chem Anticancer Agents 1:113-130

Bordoni A, Biagi P, Hrelia S (1999) The impairment of essential fatty acid metabolism as a key factor in doxorubicin-induced damage in cultured rat cardiomyocytes. Biochim Biophys Acta 25:100-106

Coakley M, Banni S, Johnson MC, Mills S, Devery R, Fitzgerald G, Paul Ross R, Stanton C (2009) Inhibitory effect of conjugated alpha-linolenic acid from bifidobacteria of intestinal origin on SW480 cancer cells. Lipids 44:249-256

Das UN (2004) From bench to the clinic: gamma-linolenic acid therapy of human gliomas. Prostaglandins Leukot Essent Fat Acids 70:539-552

De Roos B, Mavrommatis Y, Brouwer IA (2009) Long-chain n-3 polyunsaturated fatty acids: new insights into mechanisms relating to inflammation and coronary heart disease. Br J Pharmacol $158: 413-428$

Engelbrecht TN (2011) Corneum lipid model membranes: neutron diffraction studies based on the example oleic acid. Biochim Biophys Acta 1808:2798-806 
Germaini E, Chajes V, Cognault S, Lhuillery C, Bougnoux P (1998) Enhancement of doxorubicin cytotoxicity by polyunsaturated fatty acids in the human breast tumor cell line MDA-MB-231: relationship to lipid peroxidation. Int J Cancer 9:578-583

Gewirtz DA (1999) A critical evaluation of the mechanisms of action proposed for the antitumor effects of the anthracycline antibiotics adriamycin and daunorubicin. Biochem Pharmacol 57:727-741

Hidayat AT, Yusuf M, Bachti HH, Diantini A, Zainuddin A (2018) Computational model of docxorubicin conjugate with docosahexaenoic acid and integrin $\alpha v \beta 3$ ligand for anticancer. J Appl Pharm Sci 8:1-6

Huan ML, Zhou SY, Teng ZH, Zhang BL, Liu XY, Wang JP, Mei QB (2009) Conjugation with alpha-linolenic acid improves cancer cell uptake and cytotoxicity of doxorubicin. Bioorg Med Chem Lett 19:2579-2584

Jaracz S, Chen J, Kuznetsova LV, Ojima I (2005) Recent advances in tumor-targeting anticancer drug conjugates. Bioorg Med Chem 13:5043-5054

Johnson BA, Cheang MS, Goldenberg GJ (1986) Comparison of adriamycin uptake in chick embryo heart and liver cells an murine L5178Y lymphoblasts in vitro: role of drug uptake in cardiotoxicity. Cancer Res 46:218-223

Jóźwiak M, Struga M, Roszkowski P, Filipek A, Nowicka G, Olejarz W (2019) Anticancer effects of alloxanthoxyletin and fatty acids esters-in vitro study on cancer HTB-140 and A549 cells Biomed Pharmacother 110:618-630

Koralek DO, Peters U, Andriole G, Reding D, Kirsh V, Subar A, Schatzkin A, Hayes R, Leitzmann MF (2006) A prospective study of dietary alpha-linolenic acid and the risk of prostate cancer (United States). Cancer Causes Control 17:783-791

Kuznetsova L, Chen J, Sun L, Wu X, Pepe A, Veith JM, Pera P, Bernacki RJ, Ojima I (2006) Syntheses and evaluation of novel fatty acid-second-generation taxoid conjugates as promising anticancer agents. Bioorg Med Chem Lett 16:974-977

Lampidis TJ, Johnson LV, Israel M (1981) Effects of adriamycin on rat heart cells in culture: Increased accumulation and nucleoli fragmentation in cardiac muscle v. non-muscle cells. J Mol Cell Cardiol 13:913-924

Lenaz L, Page JA (1976) Cardiotoxicity of adriamycin and related anthracyclines. Cancer Treat Rev 3:111-120

Liang Ch-h (2014) Synthesis of doxorubicin $\alpha$-linolenic acid conjugate and evaluation of its antitumor activity. Mol Pharm 11 (5):1378-1390

Maheo K, Vibet S, Steghens JP, Dartigeas C, Lehman M, Bougnoux P, Gore J (2005) Differential sensitization of cancer cells to doxorubicin by DHA: a role for lipoperoxidation. Free Radic Biol Med 15:742-751

Marnett LJ, Riggins JN, West JD (2003) Endogenous generation of reactive oxidants and electrophiles and their reactions with DNA and protein. J Clin Investig 111:583-593

Meng-lei H, Si-yuan Z, Zeng-hui T, Bang-le Z, Xin-you L, Jie-pin W, Qi-bing M (2009) Conjugation with a-linolenic acid improves cancer cell uptake and cytotoxicity of doxorubicin. Bioorg Med Chem Lett 19:2579-2584

Mielczarek-Puta M, Otto-Ślusarczyk D, Chrzanowska A, Filipek A, Graboń W (2019) Telmisartan influences the antiproliferative activity of linoleic acid in human colon cancer cells. Nutr Cancer 16:1-12
Minotti G, Menna P, Salvatorelli E, Cairo G, Gianni L (2004) Anthracyclines: molecular advances and pharmacologic developments in antitumor activity and cardiotoxicity. Pharmacol Rev 56:185-229

Narang AS, Desai DS (2009) Anticancer Drug Development. In: Lu Y, Mahato R (eds) Pharmaceutical Perspectives of Cancer Therapeutics. Springer, New York, NY, pp 49-92

Narayanan NK, Narayanan BA, Reddy BS (2005) A combination of docosahexaenoic acid and celecoxib prevents prostate cancer cell growth in vitro and is associated with modulation of nuclear factor-kappaB, and steroid hormone receptors. Int $\mathrm{J}$ Oncol 26:785-792

Neubig R, Spedding M, Kenakin T, Christopoulos A (2003) International Union of Pharmacology Committee on Receptor Nomenclature and Drug Classification. XXXVIII. Update on terms and symbols in quantitative pharmacology. Pharmacol Rev 55:597-606

Oakes SG, Schlager JJ, Santone KS, Abraham RT, Powis G (1990) Doxorubicin blocks the increase in intracellular $\mathrm{Ca}++$, part of a second messenger system in N1E-115 murine neuroblastoma cells. J Pharmacol Exp Ther 252:979-983

Pessah IN, Durie EL, Schiedt MJ, Zimanyi I (1990) Anthraquinonesensitized $\mathrm{Ca} 2+$ release channel from rat cardiac sarcoplasmic reticulum: possible receptor-mediated mechanism of doxorubicin cardiomyopathy. Mol Pharm 37:503-514

Piorecka K, Stanczyk W, Florczak M (2017) NMR analysis of antitumor drugs: doxorubicin, daunorubicin and their functionalized derivatives. Tetrahedron Lett 58:152-155

Sauer LA, Dauchy RT, Blask DE (2000) Mechanism for the antitumor and anticachectic effects of n-3 fatty acids. Cancer Res 60:5289-5295

Sauer LA, Dauchy RT, Blask DE (2001) Polyunsaturated fatty acids, melatonin, and cancer prevention. Biochem Pharmacol 61:1455-1462

Tanmahasamut P, Liu J, Hendry LB, Sidell N (2004) Conjugated linoleic acid blocks estrogen signaling in human breast cancer cells. J Nutr 134:674-680

Wang Y, Li L, Jiang W, Yang Z, Zhang Z (2006) Synthesis and preliminary antitumor activity evaluation of a DHA and doxorubicin conjugate. Bioorg Med Chem Lett 16:2974-2977

Weiss RB (1992) The anthracyclines: Will we ever find a better doxorubicin? Semin Oncol 19:670-686

Willner D, Trail PA, Hofstead SJ, King DH, Lasch SJ, Braslawsky GR, Greenfield RS, Kaneko T, Firestone RA (1993) (6-Maleimidocaproyl)hydrazone of doxorubicin-a new derivative for the preparation of immunoconjugates of doxorubicins. Bloconjugate Chem 4:521-527

Xu J, Mao W (2016) Overview of research and development for anticancer drugs. J Cancer Ther 7:762-772

Young RC, Ozols RF, Myers CE (1981) The anthracycline antineoplastic drugs. N Engl J Med 305:139-153

Zajdel A, Wilczok A, Latocha M, Dzierżewicz Z (2010) Effect of polyunsaturated fatty acids on doxorubicin cytotoxicity in glioma cells in vitro. Adv Clin Exp Med 19:481-487

Zunina F, Gambetta R, Di Marco A (1975) The inhibition in vitro of DNA polymerase and RNA polymerases by daunomycin and adriamycin. Biochem Pharmacol 24:309-311 